Андрощук О. В., канд. психол. наук

(0000-0002-1032-7459)

Центр воєнно-стратегічних досліджень Національного університету оборони України імені Івана Черняховського, Київ

\title{
Аналіз застосування світових підходів для створення інформаційної інфраструктури Міністерства оборони України
}

Резюме. У статті розглядаються методологічні підходи щодо управління створенням інформаційної інфраструктури корпоративного рівня, що в світовій практиці застосовуються протягом її життєвого циклу. Унаслідок проведеного дослідження запропоновано підходи щодо застосування кращих світових практик для створення інформаційної інфраструктури Міністерства оборони України.

Ключові слова: інформаційна інфраструктура; IT-менеджмент; інформаційне забезпечення; управління вимогами.

Постановка проблеми. Перехід до нових стратегій реалізації державної інформаційної політики в Україні та використання інформації в цивільному та оборонному секторі доводить, що на сьогодні наша держава не може претендувати на конкурентоспроможність без ефективної інформаційної інфраструктури. У сфері інформатизації під поняттям інформачійна інфраструктура розуміють сукупність територіально розподілених інформаційних систем, інформаційно-телекомунікаційних мереж, систем і засобів захисту інформації, а також організаційних структур, які забезпечують іiі ефективне функціонування [1].

Особливо актуальною в сучасних умовах $є$ проблема інформатизації Збройних Сил (3С) України, одним 3 напрямів якої $\epsilon$ створення сучасної інформаційної інфраструктури Міністерства оборони (МО) України. Наявна інформаційна інфраструктура не повною мірою відповідає завданням, покладеним на МО України та ЗС України, має децентралізовану архітектуру, що призвело до виникнення великої кількості розрізнених інформаційних систем (IC), для підтримки яких потрібно використовувати значні ресурси та утримувати великий штат чергового i обслуговуючого персоналу. Інформаційна взаємодія між цими системами практично відсутня або здійснюється фрагментарно за окремими напрямами, що призводить до дублювання та недостатньої достовірності та повноти інформації.

3 аналізу стану використання IC, інформаційно-телекомунікаційного,

технічного, інженерного обладнання та нормативно-правового забезпечення, зрозуміло, що існуючий стан обумовлено недосконалістю підходів щодо управління створенням інформаційної інфраструктури, основними недоліками яких є:

1) організаційна розпорошеність i функціональна розрізненість існуючих IC;

2) відсутність централізованого планування розвитку інформаційної інфраструктури та аудиту стану впровадження інформаційних технологій;

3) недосконалість та неповнота нормативно-правового регулювання у галузі створення IC на всіх етапах їх життєвого циклу (від проєктування до утилізації);

4) відсутність єдиних методологічних, технічних та організаційних принципів i підходів щодо створення IC та впровадження інформаційних технологій;

5) відсутність стандартів обміну даними між IC для забезпечення взаємосумісності;

6) відсутність організаційно-технічної платформи 3 централізованими сервісами доступу, збереження, обробки i обміну даними;

7) недостатня розгалуженість інформаційно-телекомунікаційних мереж i швидких каналів передачі даних;

8) недостатня розробленість питань захисту інформації (інформаційних ресурсів) та висока вартість проведення заходів зі створення комплексних систем захисту інформації;

9) відсутність єдиної технічної підтримки забезпечення функціонування IC, навчання та підтримки користувачів.

Відповідно, актуальним завданням $\epsilon$ пошук шляхів створення сучасної інформаційної інфраструктури МО України.

Аналіз останніх досліджень та публікацій. Процес створення інформаційної інфраструктури є багатоступінчастим. Як будь-який складний високотехнологічний процес, проєкт створення інформаційної інфраструктури має свій життєвий цикл 
(ЖЦ), який представляється як сукупність взаємопов'язаних процесів послідовної зміни стану інформаційної інфраструктури, які відбуваються під час створення, функціонування та супроводження складових інфраструктури від визначення вимог до завершення їх використання [2].

У світі існує низка методологій i стандартів, які регламентують етапи створення інформаційної інфраструктури та процеси ЖЦ iï складових. Серед найвідоміших слід виділити:

\section{Business System Planning}

методологія організаційного планування компанії IBM на основі методу структурування інформації з використанням матриць перетину бізнес-процесів, функціональних підрозділів, функцій системи обробки даних, інформаційних систем, інформаційних об'єктів, документів і баз даних [3].

Custom Development Method (CDM) методика компанії Oracle 3 розроблення прикладних IC на основі використання заготовок проєктних документів, розрахованих на використання класичної моделі ЖЦ [58].

\section{Rational Unified Process}

методологія розроблення забезпечення (ПЗ) компанії IBM, яка пропонує модель розроблення, що включає у себе чотири фази: початок, дослідження, побудова та впровадження. Кожна фаза може бути розбита на етапи (ітерації). Проходження через чотири головні фази називається циклом розроблення, який може повторюватися, якщо робота над проєктом не завершується [4].

Microsoft Solution Framework (MSF) методологія ідентична до RUP, що також включає чотири фази: аналіз, проєктування, розроблення, стабілізація, і $є$ ітераційною та передбачає використання об'єктноорієнтованого моделювання [5].

\section{Extreme Programming (XP)}

методологія розроблення ПЗ, яка отримала назву екстремального програмування, базується на прийомах організації командної роботи, ефективної комунікації між замовником та виконавцем в період усього проєкту [6].

Continuous Acquisition and Life cycle Support (CALS) - концепція безперервної інформаційної підтримки ЖЦ продукту на всіх його стадіях, яка призначена для підвищення ефективності та якості процесів ЖЦ продукту завдяки застосуванню безпаперових технологій.
ГОСТ 34.601-90 - стандарт, що розповсюджується на автоматизовані системи та встановлює стадії та етапи їх створення. Крім того, у стандарті міститься опис робіт на кожному етапі.

ISO/IEC/IEEE 12207:2017 - стандарт на процеси та організацію ЖЦ програмного забезпечення. Стандарт не містить описів фаз, стадій та етапів [7].

ДСТУ ISO/IEC/IEEE 15288:2016

стандарт на процеси ЖЦ систем, що стосуються різноманітних областей: системної інженерії, програмування, управління якістю, людськими ресурсами, безпекою та ін. [8].

Незважаючи на досить широкий вибір наведених підходів, їх застосування на практиці здебільшого орієнтовано на управління ЖЦ окремих складових інформаційної інфраструктури. Складність створення інформаційної інфраструктури військового відомства пов'язана 3 наявністю значної кількості модифікацій іiї складових, постійними змінами функціонального середовища, проблемами стандартизації, уніфікації, що потребує застосування багаторівневої моделі ЖЦ. Саме тому актуальним $\epsilon$ завдання аналізу практичного застосування світових підходів для створення інформаційної інфраструктури МО України.

Метою статті є обгрунтування шляхів створення інформаційної інфраструктури Міністерства оборони України на основі застосування найкращих світових практик.

Виклад основного матеріалу. На цей час у провідних країнах світу розробляється цілий пласт проблем, пов'язаних 3 архітектурним підходом до управління складними організаційно-технічними об'єктами (рівня підприємства, організації, військового відомства тощо) та їх інформаційною інфраструктурою. Стандарт ДСТУ ISO/IEC/IEEE 15288:2016 визначає поняття системної архітектури, як концептуальну організацію складної системи, яка втілюється в ії елементах, їх взаємодії між собою та із середовищем, а також принципах, що $є$ основою для прийняття рішень щодо іiі проєктування і еволюціонування. Такий підхід 3 погляду управлінської діяльності розглядає архітектуру інформаційної інфраструктури як складову більш загального поняття архітектури організації (Enterprise Architecture).

Відомі міжнародні компанії IBM, Hewlett Packard, Microsoft виділяють чотири основні погляди на архітектуру інформаційної інфраструктури організації [9]: 
бізнес-архітектура $\quad-\quad$ описуються функціональні процеси організації, а також стратегії розвитку організації;

інформаційна архітектура - описуються необхідні для реалізації функціональних процесів дані та використовується як зв'язок між даними і процесами;

архітектура застосунків - вказується, яке прикладне ПЗ використовується або має використовуватися для обробки даних;

технологічна архітектура - описується структура апаратного забезпечення, необхідного для підтримання архітектури застосунків та інформаційної архітектури.

Як видно 3 наведених визначень, концепція архітектури інформаційної інфраструктури організації полягає у визначенні підходів щодо використання інформаційних i технологічних ресурсів відповідними функціональними процесами. Зазначені архітектурні підходи отримали широке визнання, i за ініціативою різних організацій i фондів, що займаються впровадженням інформаційних технологій (IT), були опубліковані у вигляді бібліотек найкращих практик, що описують фреймворки (англ. frameworks - робочі моделі) управління процесами на різних рівнях архітектури інформаційної інфраструктури (далі - ITпроцесами). Мета ініціативи - зібрати і поділитись передовим досвідом управління застосуванням IT між організаціями по всьому світу.

Відповідно до наведених рівнів архітектури інформаційної інфраструктури слід виділити такі передові підходи:

Business Information Services Library (BISL) - бібліотека, що описує IT-процеси забезпечення надання інформації 3 погляду задоволення потреб іiі споживачів;

Control Objectives for Information and related Technology (CОВIT) - збірка принципів управління застосуванням IT-процесів та проведення їх аудиту з погляду стратегічного керівництва організації;

Application Services Library (ASL) бібліотека, що описує IT-процеси управління розробленням, супроводженням та оновленням прикладного ПЗ;

Information Technology Infrastructure Library (ITIL) - бібліотека, що описує ITпроцеси управління технологічною інфраструктурою.

Наведені підходи розглядають функціональні процеси організації, як множину завдань, для вирішення яких інформаційною інфраструктурою надається певний набір послуг - так званих IT-сервісів. 3 позиції загальної теорії систем, IT-сервіси $\epsilon$ системоутворюючими факторами, які виконують роль керованих об'єктів у системі управління інформаційною інфраструктурою. Вироблення керуючих впливів здійснюється керівниками функціональних процесів (функціональним IT-менеджментом), який відображає потреби підрозділів організації в інформаційному забезпеченні та $є$ засобом управління інфраструктурою і застосунками. Такий підхід до управління IT-сервісами характеризується орієнтованістю на функціональні процеси i їx максимально тісною зв'язкою 3 можливостями технологічної інфраструктури. Це забезпечується такими обов'язковими етапами створення інформаційної інфраструктури:

ідентифікація функціональних та інформаційних процесів організації (як існуючих, так і запланованих) і їх вимог до ITсервісів;

відображення інформаційних процесів на елементи застосунків i технологічної інфраструктури;

визначення вимог до мережевих компонентів, серверного обладнання, систем зберігання даних i застосунків для забезпечення продуктивності та доступності конкретних технологічних компонентів;

моніторинг заданих параметрів якості надання ІТ-сервісів і звітність за його результатами (дає змогу контролювати їх досягнення).

Рекомендації BISL, COBIT, ASL та ITIL відрізняються за діапазоном завдань, які вони вирішують, і підходами, які використовують. Для розуміння можливостей використання зазначених підходів слід проаналізувати кожен з них і порівняти.

BISL - описує такі види діяльності із забезпечення надання інформації: ефективне планування, збір, організація, використання, контроль, поширювання i знищення інформації. Ця інформація пов'язана 3 активним управлінням, супроводженням i підтриманням функціональних процесів. Розроблення моделі інформаційної політики організації знаходиться в зоні відповідальності функціонального ITменеджменту. Вихідними даними для формування моделі інформаційної політики $\epsilon$ опис основних функціональних процесів, зв'язки між стратегічними цілями організації і функціональними процесами; зв'язки між застосунками, що виконують обробку даних, i функціональними процесами; зв'язки між 
застосунками. Функціональні процеси умовно розділяються залежно від рівня деталізації на процеси і функції, що визначають діяльність 3 використання інформації, інформаційних технологій і технологічної інфраструктури.

У BISL визначено 23 IT-процеси, об'єднані в сім кластерів, що утворюють три рівні процесів управління інформаційним забезпеченням: операційний, управлінський i стратегічний [10].

Процеси операційного рівня відповідають за визначення вимог до інформаційного забезпечення i безперервне підтримання відповідних функціональних процесів.

На управлінському рівні розглядаються специфічні вимоги користувачів до прикладного ПЗ, забезпечуючи управління його використанням 3 погляду планування, рентабельності, потреб, рівнів якості надання IT-сервісів.

На стратегічному рівні розглядаються зв'язки між функціональними процесами i ï інформаційною підтримкою. На рівні функціонального-процесу формуються вимоги до інформації, що пред'являються окремими функціональними процесами. Цей рівень забезпечує визначення політики майбутнього інформаційного забезпечення, формуючи стратегію його розвитку.

COBIT - визначає набір універсальних методів управління IT-процесами для контролю за їх виконанням, аудиту та надання звітності [11]. Згідно з СОВIT, процес - це дія, спрямована на досягнення результату за умови оптимального використання ресурсів, яка може коригуватися під час іiі виконання. Усі ресурси, задіяні у процесі, структуруються таким чином, щоб максимально ефективно виконувати цей процес. Більшість процесів $\epsilon$ сталими або змінюються нечасто, порівняно 3 організаційними об'єктами (співробітники, відділи, департаменти та ін.). Упровадження методології СОВIT, як правило, не обмежується рамками одного відділу або департаменту, а зачіпає всю структуру організації.

COBIT охоплює усі IT-процеси, які згруповані за напрямами:

планування та організація - група процесів, які визначають напрями щодо впровадження рішень і забезпечення ITсервісів;

придбання i впровадження - група процесів, які забезпечують впровадження рішень і надання на їх основі IT-сервісів; експлуатація та супроводження - група процесів, які реалізують функціональні процеси і роблять їх доступними для кінцевих користувачів;

моніторинг - група процесів, які виконують спостереження за всіма ITпроцесами для вчасного реагувати на інциденти і проблеми.

Особливістю підходу СОВІТ є наявність у ньому моделі зрілості інформаційної інфраструктури. Використання моделі зрілості робить цей підхід найбільш ефективним для визначення цілей у сфері IT, побудови системи збалансованих показників для проведення внутрішніх і зовнішніх аудитів ITпроцесів. Усі ресурси, які використовуються об’єктами контролю, оцінюються 3 погляду їх відповідності критеріям, які випливають із завдань організації: ефективність, технічний рівень, безпека, цілісність, придатність, узгодженість, надійність. На підставі результатів аудиту за рівнями зрілості можливо сформувати повну, об'єктивну та актуальну інформацію про поточний стан ITпроцесів, визначити можливі рішення щодо зміни ситуації, заходи щодо вдосконалення IT-процесів, перспективи та ризики щодо їх реалізації.

ASL - описує види діяльності щодо управління застосунками протягом їх ЖЦ, а саме проєктуванням, тестуванням, супроводженням, обслуговуванням, розширенням i оновленням економічно виправданими методами [12].

Важливим аспектом підходу ASL $є$ проактивний підхід до надання IT-сервісів. Він дає змогу передбачити розвиток ситуації i забезпечувати виявлення можливих сценаріїв роботи на декількох рівнях управління:

на рівні політики і стратегії управління застосунків, де здійснюється коригування способів надання IT-сервісів на ранніх стадіях, для задоволення майбутніх потреб;

на рівні стратегії, де планується створення застосунків, проводиться актуалізація сценаріїв i методів, які призводять до бажаного результату;

на рівні процесів управління, де проводиться управління якістю застосунків (зокрема управління проблемами);

на операційному рівні (у процесі експлуатації), для здійснення активної взаємодії всіх зацікавлених сторін і надання звітності.

Рекомендації ASL можуть бути використані як: 
інструмент структурування діяльності (описує діяльність з управління застосунками, допомагаючи визначити, де i яка робота проводиться чи не проводиться, або здійснюється неявно);

інструмент комунікацій (забезпечує чітку понятійну основу, даючи визначення різним поняттям та видами діяльності, забезпечуючи взаємодії між зацікавленими сторонами на основі загальної системи понять);

інструмент проєктування i впровадження застосунків (встановлює систему взаємозв'язків між різними видами діяльності, надаючи інструменти для впровадження ПЗ).

ITIL - описує процесний підхід до надання і підтримки IT-сервісів [13]. Він пропонує структурований опис найбільш часто використовуваних IT-процесів, їх цілей i параметрів, а також зв'язків між окремими ITпроцесами. Кожен процес детально описаний, надано рекомендації щодо його впровадження та реалізації. Згідно з підходом ITIL виділяють три основні групи процесів:

планування розвитку IT-сервісів: проєктування, планування, розширення;

надання IT-сервісів: управління

інцидентами i проблемами, управління конфігурацією і змінами, управління релізами; управління наданням (підтримка) ITсервісів: управління рівнем обслуговування, фінансове управління IT-сервісами, управління готовністю, управління безперервністю обслуговування, управління потужностями.

Однією з основних цілей впровадження ITIL $€$ підвищення якості надання IT-сервісів в умовах обмеженого бюджету, низької кваліфікації персоналу, складної конфігурації систем, швидких змін функціональних процесів. Ця методологія передбачає надання IT-сервісів на основі попередньої домовленості, яка виражається угодою про рівень послуг (SLA - Service Level Agreement). Контроль за якістю послуг грунтується на процесі управління рівнем сервісу (SLM Service Level Management). Параметри якості IT-сервісу і результати їх вимірювання мають формулюватися 3 погляду функціонального IT-менеджменту, тобто мають визначати вимоги до можливостей ПЗ (які послуги ПЗ має надавати, яку реакцію демонструвати у відповідь на певні дії і в певних ситуаціях).

Однією з найважливіших умов побудови ефективної інформаційної інфраструктури $\epsilon$ підтримка IT-сервісів (Service Support). Для якісної підтримки IT-сервісів необхідні: служба технічної підтримки (Service Desk), система управління інцидентами (Incident Management), система управління проблемами (Problem Management), система управління конфігураціями (Configuration Management), система управління змінами (Change Management) i система протоколювання версій реалізації (Release Management). У разі потреби поліпшення надання IT-сервісів, проводять їх змінення в рамках процесу управління змінами (Change Management) під час надходження запиту на зміну (RFC Request For Change) до служби технічної підтримки. Це дає змогу підвищити якість ITсервісів для виконання службових завдань i зменшити витрати на їх надання.

Для забезпечення максимальної ефективності надання IT-сервісів в ITIL пропонуються ключові процедури, що включають в себе управління сервісами мережі (Network Service Management), станом елементів технічної інфраструктури (Operations Management), локальними комп'ютерами (Management of Local Processors), a також інсталяиією $i$ експлуатаціюо обчислювальних систем (Computer Installation and Acceptance). B ITIL також описані зв'язки між етапами розроблення та підтримки ПЗ, зокрема розглядається управління життєвим цииклом П3 (Software Lifecycle Support) і тестуванням IT-сервісів (Testing an IT Service for Operational Use).

Порівняння підходів. BISL, COBIT, ASL i ITIL розглядають управління інформаційною інфраструктурою з різних боків:

BISL - розглядає необхідні види діяльності 3 управління інформаційним забезпеченням функціональних процесів організації та дає чітке розмежування між стратегічним керівництвом функціональними процесами, управлінням інформацією, користувачами та постачальниками ITсервісів;

СОВІT - управління діяльністю, ресурсами i ризиками щодо забезпечення надання IT-сервісів;

ASL - описує види діяльності щодо управління ПЗ, що реалізує функціональність IT-сервісів;

ITIL - описує множину аспектів взаємодії 3 користувачами IT-сервісів, визначає ролі та обов'язки, пов'язані 3 підтримкою технологічної інфраструктури.

Таким чином, рекомендації BISL, COBIT, ASL i ITIL можна розглядати як 
взаємодоповнюючі підходи. Можлива рівнях архітектури інформаційної взаємодія розглянутих підходів на різних інфраструктури наведена на рис. 1.

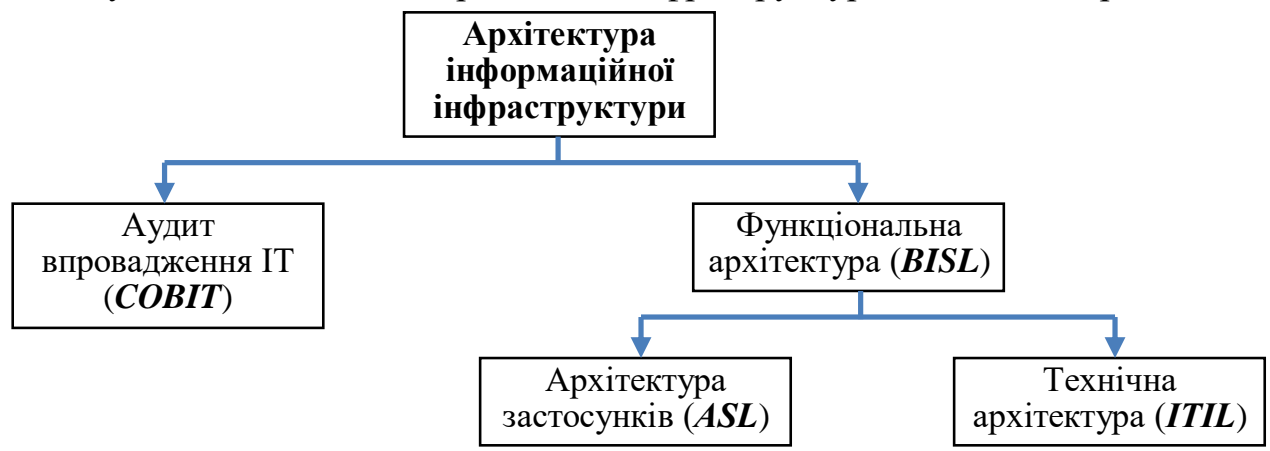

Рис. 1. Схема взаємодії підходів BISL, COBIT, ASL i ITIL

Взаємне використання підходів BISL, COBIT, ASL i ITIL дає змогу забезпечити усунення основних недоліків щодо створення інформаційної інфраструктури МО України: BISL - недоліки 1-2, COBIT - 2-4, 6; ASL - 4, 5; ITIL - 6-9.

Висновки. У статті проведено аналіз світових підходів, що запропоновані рекомендаціями бібліотек найкращих практик управління IT-процесами на різних рівнях архітектури інформаційної інфраструктури. Визначено, що доцільним $\epsilon$ застосування інтегрованого підходу на основі найкращих практик BISL, COBIT, ASL i ITIL, що дасть змогу підняти на якісно новий рівень процеси створення та управління інформаційною інфраструктурою МО України.

\section{СПИСОК ВИКОРИСТАНОЇ ЛІТЕРАТУРИ}

1. Про затвердження Концепції інформатизації Міністерства оборони України : наказ Міністерства оборони України від 17.09.2014 р. № 650. URL: https://zakon.rada.gov.ua/rada/show/ v0650322-14\#Text (дата звернення: 04.06.2020).

2. Інженерія систем i програмного забезпечення. Процеси життєвого циклу програмного забезпечення (ISO/IEC 12207:2008, IDT). [Чинний від 2016-01-01].

3. Zachman John. Business Systems Planning and Business Information Control Study: A comparisment. IBM Systems Journal. Vol 21, No 3, 1982. Р. 31-53.

4. Вернадов А. М. Программирование программного обеспечения экономических информационных систем. Москва : Финансы и статистика, 2002. 349 с.

5. Кратчен Филипп. Введение в Rational Unified Process. Москва : Вильямс, 2002. 240 с.

6. Обзор Microsoft Solutions Framework (MSF) URL: https://msdn.microsoft.com/ru-ru/library/ jj161047(v=vs.120).aspx (дата звернення: 04.06.2020).

7. Ауер К., Миллер Р. Экстремальное программирование. Санкт-Петербург : Питер, 2004. $368 \mathrm{c}$.

8. Інженерія систем і програмного забезпечення. Процеси життєвого циклу систем (ISO/IEC 15288:2008, IDT). [Чинний від 2016-01-01].

9. Обзор архитектуры Microsoft URL: https://msdn.microsoft.com/ru-ru/library/ ee872883.aspx (дата звернення: 06.06.2020).

10. Ван дер Полс Р., Донац Р., Ван Аутфорст Ф. BiSL. Сборник описаний процессов для управления бизнес-информацией. Москва : 2014. $191 \mathrm{c}$.

11. COBIT. An ISACA Framework. URL: http://www.isaca.org/cobit (дата звернення: 06.06.2020).

12. ASL BiSL Foundation. URL: http://www.aslbislfoundation.org/ru/bisl (дата звернення: 04.06.2020).

13. What is ITIL Best Practice. ITIL. AXELOS. URL: https://www.axelos.com/best-practice-solutions/ itil/what-is-itil (дата звернення: 04.06.2020).

Стаття надійшла до редакційної колегії 06.07.2020

\section{Analysis of the application of global approaches to the creation of information infrastructure of the Ministry of Defense of Ukraine}

\section{Annotation}

The transition to new strategies for the implementation of state information policy in Ukraine and the use of information in the civil and defense sectors, proves that today our state cannot claim competitiveness without an effective information infrastructure. The existing information infrastructure does not fully meet the tasks assigned to the Ministry of Defense of Ukraine and the Armed Forces of Ukraine, has a decentralized architecture, which has led to a large number of disparate information systems (IS), which require significant resources and large staff. 
As the analysis of the state of use of IP, information and telecommunication, technical, engineering equipment and regulatory support, the current state is due to the imperfection of approaches to managing the creation of information infrastructure. The main disadvantages are:

- organizational dispersion and functional diversity of existing IP;

- lack of centralized planning of information infrastructure development and audit of the state of information technology implementation;

- Lack of common methodological, technical and organizational principles and approaches to the creation of IP and implementation of information technology and others.

The article analyzes the global approaches proposed by the recommendations of libraries of best practices in IT process management at different levels of information infrastructure architecture. It is determined that it is expedient to apply an integrated approach based on the best practices of BISL, COBIT, ASL and ITIL, which will allow to raise to a qualitatively new level the processes of creating and managing the information infrastructure of the Ministry of Defense of Ukraine.

Keywords: system architecture; IT management; information support; information support management; defense sector; requirements management. 